\title{
The University Presidents and the Construction and Development of World-Class Universities-An Empirical Analysis Based on MIT and Tsinghua University
}

\author{
Yu Yue, Sun Keli \\ Tianjin University, Tianjin, 300350
}

\begin{abstract}
The university president should be an educator, a manager, or an operator who can boost the construction and development of the university. By systematically reviewing the ideas and strategies of several famous university presidents in two world-class universities, this paper analyzes the roles and duties of university presidents in the construction and development of world-class universities, and explains the successful experience of university presidents in promoting the construction and development of world-class universities. In view of this new situation, this paper can provide a useful reference for "double first-class" construction.
\end{abstract}

Keywords-University presidents; World-class universities; MIT; Tsinghua University

\section{INTRODUCTION}

Mr. Tao Xingzhi, a famous educator in China, once said: "the principal is the soul of a school." Looking at the history of the development of famous universities at home and abroad, it is not difficult to find that the birth of every famous university is the inevitable result of the birth of one or several famous university presidents. Similarly, the birth of every famous president is also the necessary condition for the birth of every famous school. In short, excellent universities need excellent leaders, and world-class universities need world-class presidents.

\section{THE ROLES AND DUTIES OF UNIVERSITY PRESIDENTS}

\section{A. The Roles of University Presidents}

The university president is the "head of the university". As planners and promoters of the construction and development of universities, they need to abide by the relevant rules or requirements and clarify their mission or position. Specifically, the university president should play the following three roles:
1) The University President Should Be an Educator with Educational Literacy

The university should be a place to impart comprehensive knowledge and to study profound knowledge. The primary function of the university should be to cultivate talents. "In any case, the university should make its own sacred mission of seeking truth, creating knowledge, cultivating talents and leading society." [1] As a leader and decision-maker, the university president should be an educator with a wide range of educational literacy. They are engaged in the practice of education and teaching management; they have a certain understanding of education, universities, teachers and students; they know the rules of education and teaching and the laws of personnel training; and they can form their own unique educational ideas and systematic educational thoughts. Only with a systematic educational philosophy, can the university president establish a world-class university. At this point, educator-type university presidents in the era of the Republic of China, such as Cai Yuanpei, Mei Yiqi and Zhu Kezhen, have set a successful example for us.

2) The University President Should Be a Manager with Management Experience

As the core manager, university presidents play a leading role in school management activities. Therefore, the university president should be an excellent manager with rich management experience. Through their own overall planning, university presidents balance the interests of all parties, so that the people, money, material, time, space, information and other resources in the universities can give full play to the overall function of the best. At present, the reform of educational management system in China is deepening day by day, which puts forward higher demands on the management ability of university presidents. The university presidents should adhere to a scientific management view, be good at grasping the overall situation and assessing the situation to push the development of the university to a new historical stage. 
3) The University President Should Be a Operator with Overall Awareness

Education does not exist in a vacuum and the university has also stepped out of the ivory tower. The relationship between the development of university and social development is getting closer and closer. The university is an integral part of the social organism. The university president, as the leader of a social institution, should be an intelligent, courageous and visionary operator. First of all, the university president should be politically sensitive, be familiar with the country's educational policies and policies, be able to grasp the needs of the country's development, properly integrate the policy principles determined by superiors with the actual conditions of the school, and win national funding for education for the school; Second, the university president should clarify the needs of social development, establish a good relationship with all sectors of society, pay attention to creating and maintaining the image of himself and the university he represents in the social activities, and actively seek financial support from society; Finally, the university president should be able to capture the opportunities for development, make the plans for the development of the university, and be responsible for the development and operation of the school.

\section{B. The Duties of University Presidents}

Mr. Liu Daoyu, a famous contemporary educator in China and the former president of Wuhan University, once said: "The principal should have a good command of the school." This "command" means knowing the direction of running schools, the strategy for governing schools and the method of cultivating talents. In summary, the duty of principal is to set policies and cultivate talents. Specifically speaking, it is able to accurately position the university, and at the same time do a good job in development planning; coordinate the interests of all parties, and at the same time do a good job of power distribution; keep the balance between teaching and research, and at the same time do a good job in the development of the discipline; care about the development of teachers and students, and at the same time do a good job of communication.

The principal is the soul of a school and the mirror of the school. An excellent principal who can create a truly famous school will enjoy a high degree of prestige among teachers and students with his own unique personality charm, academic cultivation, management method, profound knowledge and the ability to reform.[2] Prestigious universities must have famous principals! University presidents influence the construction of university and play a key role in the process of university development.

\section{THE ACHIEVEMENTS OF THE PRESIDENTS: THE ORIGIN OF THE RAPID RISE OF MIT}

Massachusetts Institute of Technology (MIT), founded in 1861, is known as "the immortal academic backbone of American society". In the 2017-2018 annual list of the world's most authoritative university rankings, including the US News World University Rankings, QS World University Rankings and Times Higher Education World University Rankings, MIT ranks among the top and even tops the list. The rapid rise of MIT in more than 150 years and its development into a recognized world-class university are closely related to the achievements of the presidents. Among them, Rogers, Compton, and Gillian are the most famous.

\section{A. Rogers and the Establishment of Massachusetts Institute of Technology}

William Barton Rogers, a famous scientist in the United States, is the founder of MIT, who has twice served as president of MIT. In 1882, he fell to the stage while attending the graduation ceremony of the college. He died suddenly and devoted his entire life to serving the college.

With the rapid development of the two industrial revolutions in the United States, the demand for talents in the American society has been increasing day by day. And the subsequent Civil War also had a huge impact on American higher education. In 1861, MIT came into being with the unremitting efforts of Rogers. In 1862, Rogers was officially appointed president. And in 1865, MIT ushered in the first batch of students. In the process of creating MIT, Rogers wrote to the government three times to apply for land and construction permits. During the first ten years, he has also been raising funds in various ways and hiring outstanding teachers. Rogers not only created MIT, but also pointed out the direction for the college's future development and planned well. $\mathrm{He}$ emphasized the practicality and effectiveness of engineering technology and advocated equal emphasis on basic science and applied science. He advocated the integration of teaching and scientific research activities. And he believed that school education should be linked to social needs and that schools should serve the society. During his tenure, Rogers has turned MIT into the most outstanding engineering college in the United States. 


\section{B. Compton and the Transformation of Massachusetts Institute of Technology}

Karl Taylor Compton is a famous physicist who became the ninth president of MIT in 1930. He worked at MIT for 19 years And he was a landmark figure in leading MIT into the ranks of the world's research universities of science and engineering.

In 1926, the Rockefeller Foundation rejected assistance to MIT on the ground that "MIT is just a technical college and it is difficult to engage in basic scientific research." This led to a shortage of MIT funding and MIT was in an unprecedented crisis. As a result, Compton began to strengthen the construction of basic disciplines as soon as he took office. First of all, Compton established the Department of Physics as a breakthrough to strengthen basic science education. Afterwards, Compton set up the School of Science, established a number of laboratories, adjusted the focus of discipline construction, and created a tradition of interdisciplinary research. In addition, Compton placed emphasis on postgraduate education, upgraded Postgraduate School and raised the level of education adjusted the administrative structure of the college and reformed the management system; selected and employed a group of outstanding teachers; deepened the tradition of serving the country, consolidated the relationship between the university and the outside world and obtained financial support During his tenure of office, the series of changes he has made had far-reaching and lasting influence, which made MIT gradually develop into a science and engineering university from a university that only pays attention to engineering education.

\section{Gillian and the Sublimation of Massachusetts Institute of Technology}

In 1948, James Ryan Gillian succeeded Karl Taylor Compton as the 10th president of MIT. Before that, Gillian was already the vice president of MIT and was responsible for the research of the Lewis report.

The central argument of the Lewis report is that MIT should not only be able to create new scientific and innovative technologies, but it should also be able to link them with human values and human hopes. And the college has the responsibility to anticipate the impact of scientific and technological development on society and learn how to deal with new technical issues in a humane manner. [3]Therefore, after taking office, Gillian established the Academy of Humanities and Social Sciences, treated humanities and social sciences equally with science and engineering, and gradually transformed MIT into a comprehensive university. In addition, he also attached great importance to interdisciplinary research, implemented curriculum reform, developed postgraduate education, and raised the level of talent training. At the same time, he actively adjusted the relationship between the university and the outside and strived for financial support from the federal government and the community. By the time of the retiring of the president of Gillian, MIT has become a multidisciplinary comprehensive research university.

\section{The PERFormance OF THE PRESIDENTS: THE CAUSE OF THE BRILLIANCE OF TSINGHUA UNIVERSITY}

Tsinghua University (Qinghua), originally referred to as the Tsinghua School, was founded in 1911. It was established by the Qing Government as the preparatory school for studying in the United States, and is now known as the "cradle of engineers." As the top research universities in their respective countries, MIT has rapidly emerged as a world-class university for more than 150 years, and Tsinghua University has also become a top university in China and a world-famous university in more than 100 years. Some people say that without Mei Yiqi and Jiang Nanxiang, there would be no Tsinghua University today. It can be seen from this that in the course of Tsinghua's 100-year development, presidents Mei Yiqi and Jiang Nanxiang have made great achievements.

\section{A. Mei Yiqi and the Modernization of Tsinghua}

Mei Yiqi was appointed as the president of Tsinghua University in 1931, and concurrently served as chairman of the standing committee of the National Southwest Associated University organized by Tsinghua University, Peking University, and Nankai University during the Anti-Japanese War. He served for 17 years and made outstanding contributions to the development of Tsinghua University. And he is honored as the "everlasting president" of Tsinghua University.

First of all, Mei Yiqi advocated general education, emphasized that through general knowledge training, students should lay a solid foundation of knowledge and cultivate their adaptability. Secondly, Mei Yiqi put forward the "Master Theory". In his inaugural speech, Mei Yiqi put forward that "the so-called colleges and universities are not buildings, but masters." To this end, Mei Yiqi invited scholars to teach at Tsinghua University. Thirdly, similar to when Cai Yuanpei was in charge of Peking University in the early days, Mei Yiqi also advocated democratic management, and promoted the evolution and development of the democratic system in Tsinghua. Finally, Mei Yiqi attached great importance to Tsinghua's responsibilities to the entire country and the nation, and at the same time he actively expanded international horizons and laid the foundation for Tsinghua to approach the world's technological frontier. In addition, Mei Yiqi also made great contribution to the development of higher engineering education in China. He established a College of Engineering, developed engineering education, and trained engineers and technicians. Tsinghua cultivated Mei Yiqi, and Mei Yiqi also devoted his entire life to the development of Tsinghua. 


\section{B. Jiang Nanxiang and the Shaping of the New Tsinghua}

Jiang Nanxiang, the first president of the new Tsinghua University, took office in 1952. Since then, he has dedicated all his enthusiasm to Tsinghua University and the educational undertakings of New China. And he is praised as the "Father of Tsinghua University" in New China.

In terms of discipline layout, Jiang Nanxiang opposed the separation of science and engineering, and took MIT as an example to promote Tsinghua's transformation from a technical university to a science and engineering university, and laid the foundation for Tsinghua's development into a comprehensive university in the future. In the aspect of the construction of faculty, Jiang Nanxiang respected intellectuals and actively united with a group of professors left by the old Tsinghua University. At the same time, according to the actual situation, he introduced a group of Soviet experts. He also often quoted former president Mei Yiqi's "Master Theory". But under the new historical conditions, he also gave this view a new meaning, that is, as a master of a socialist university must be both red and professional. In terms of ideological and political work, Jiang Nanxiang attached great importance to communicate with students and pioneered the system of student political counselor which is called "double shoulder task". "Double shoulder task" refers to one shoulder picking professional learning and one shoulder picking ideological and political work.[4] In addition, Jiang Nanxiang also inherited Tsinghua's tradition of attaching importance to physical education, focused on cultivating the students' perseverance spirit. For more than ten years, Jiang Nanxiang has been exploring the "China road" for education development. He has successively put forward "one fundamental, two centers, three aspects of integration", "three stages, two points" and other theories. Due to Jiang Nanxiang, Tsinghua University has been firmly in the position of a first-class university. And Jiang Nanxiang also became a leader in the field of higher education because of Tsinghua University.

\section{THE SUCCESSFUL EXPERIENCE OF THE FAMOUS}

UNIVERSITY PRESIDENTS IN ESTABLISHING WORLD-CLASS UNIVERSITIES AND ITS ENLIGHTENMENT TO THE CONSTRUCTION OF "DOUBLE FIRST-CLASS" IN CHINA

Through combing and summarizing the course of running a school and school-running concept of several well-known presidents in two world-class universities, it is not difficult for us to find that: university presidents influence the development of universities. The characteristics of the well-known principals, such as the concept of running a school, the quality of character, and the level of specialization, all affect the construction of the university.
A. The Ideas of Running a University and the Strategies of Managing a University of University Presidents Guide the Development of the University.

From Rogers, Compton, and Gillian of MIT to Mei Yiqi and Jiang Nanxiang of Tsinghua University, all of these famous university presidents are all equipped with advanced ideas of running a university and the strategies of managing a university. The idea of the principal is a source of strength for the university's survival and development, which directly influences the style and direction of the university. They constantly improve the concept of running schools and administering schools, maintain academic freedom, respect the value of knowledge, attach importance to personnel training, pay attention to the construction of teachers, broaden the distribution of disciplines, advocate international cooperation, and actively establish a good relationship with all sectors of society.

\section{B. The Academic Aptitude and the Moral Qualities of University Presidents Promote the Development of Universities}

As can be seen from several well-known presidents of these two first-class universities mentioned above, the excellent university presidents all have unique personality charm and lofty moral qualities. They love the cause of education, know how to judge and use people, care for teachers and students and be able to devote the lifelong life to the cause of education. They also have keen vision, excellent academic ability and excellent management ability. They can keep up with the pace of development of the times, adjust the direction of development of the school, and coordinate the internal and external relationships of the university.

\section{The Specialization and Professionalization of University Presidents Influence the Development of Universities.}

Only those who understand how to educate can do a good job in education. The president of a university should be professional, not only academic but also comprehensive. They are capable of clearly positioning his or her role, leading the future direction of the university, and at the same time devoting himself or herself to the management of the university and promoting the benign development of the university. In addition, it is also important to note that the term of a university president affects the realization of leadership and the development of professionalism. Looking at the abovementioned several outstanding presidents, their tenure is relatively long. It can be seen: the performance of university presidents can not be seen in the short term, and the tenure of university presidents affect the continuity and stability of university development. In a word, the president should be guaranteed a long term to implement policies, carry out plans, and achieve the goals. 


\section{CONCLUSION}

The rise and development of a university is often accompanied by one or more famous principals [5], and the principal bears the important responsibility to lead the development of the university. Nowadays, under the background of "double first-class" construction, Chinese universities have entered an important period of strategic opportunities for the construction of world-class universities. The principals should actively learn from the experience of famous university presidents in establishing world-class universities, take measures and implement actions in talent cultivation, subject layout, faculty construction, institutional reform, and international cooperation. In short, the university presidents should "make a difference" and "have a lot to do." In addition, we should also make it clear that the construction and development of a university is neither a day's work nor the strength of a principal alone. What we can do is to strengthen our confidence, to learn from successful experience, and to move forward in the direction of world-class universities.

\section{ACKNOWLEDGMENT}

About the author:

Yu Yue, female, graduate student of grade 2017, school of education, Tianjin University, research field: higher education.

Sun Keli, male, associate professor, school of education, Tianjin University, research field: higher engineering education.

\section{REFERENCES}

[1] Wu Kangning. "Chinese Problem" in Educational Reform [M]. Nanjing: Nanjing Normal University Press, 2015:272. (In Chinese )

[2] Wang Yunlai et al. Dao and Shu: The Ideas of Running a School and the Strategies for School Governance of the Presidents of Famous Universities in China [M]. Nanjing: Nanjing University Press, 2014:351352. (In Chinese )

[3] Wang Yingjie. The University Presidents and the Directions of Running Universities: The Experience of Massachusetts Institute of Technology [J]. Comparative Education Review, 1994, No.3:6. (In Chinese )

[4] Cheng Sihui. Presidents of the famous Universities of New China [M]. Wuhan: Hubei People's Publishing House, 2007:50-51. (In Chinese )

[5] He Guoqing. University Presidents and the Development of University [J]. Educational Research, 2013, No. 3:140. (In Chinese ) 